
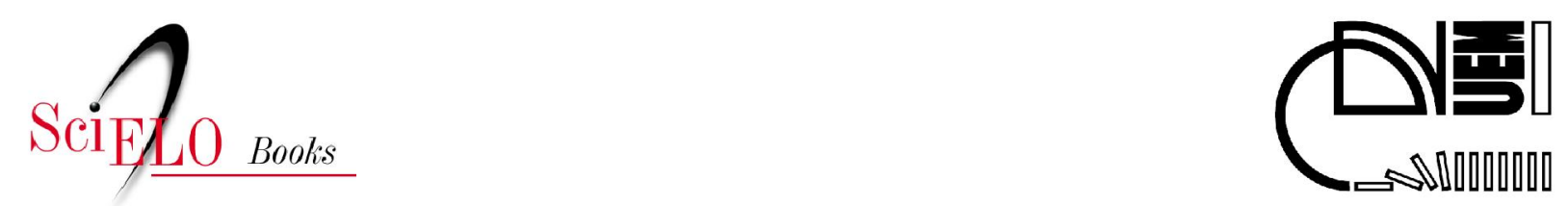

\title{
VII. As consequências econômicas e sociogeográficas dos danos causados pela geada na economia cafeeira do norte do Paraná
}

\author{
Paulo Astor Soethe (org.) \\ Daniel Martineschen (coord.) \\ Caio Heleno da Costa Pereira \\ Dionei Mathias \\ Elisete Antoniuk \\ Fernanda Boarin Boechat \\ Frederico Füllgraf \\ Natasha Pereira da Silva \\ Sibele Paulino \\ Sirlene Nair Neubauer \\ (transl.)
}

\section{SciELO Books / SciELO Livros / SciELO Libros}

SOETHE, PA., org. MARTINESCHEN, D., et al., transl. KOHLHEPP, G. As consequências econômicas e sociogeográficas dos danos causados pela geada na economia cafeeira do norte do Paraná. In: Colonização agrária no Norte do Paraná: processos geoeconômicos e sociogeográficos de desenvolvimento de uma zona subtropical do Brasil sob a influência da plantação de café [online]. Maringá: Eduem, 2014, pp. 141-158. ISBN 978-85-7628-655-4. Available from SciELO Books <http://books.scielo.org $>$.

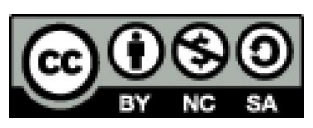

All the contents of this chapter, except where otherwise noted, is licensed under a Creative Commons Attribution-Non Commercial-ShareAlike 3.0 Unported.

Todo o conteúdo deste capítulo, exceto quando houver ressalva, é publicado sob a licença Creative Commons Atribuição Uso Não Comercial - Partilha nos Mesmos Termos 3.0 Não adaptada.

Todo el contenido de este capítulo, excepto donde se indique lo contrario, está bajo licencia de la licencia Creative Commons Reconocimento-NoComercial-CompartirIgual 3.0 Unported. 


\section{AS CONSEQUÊNCIAS ECONÔMICAS E SOCIOGEOGRÁFICAS DOS DANOS CAUSADOS PELA GEADA NA ECONOMIA CAFEEIRA DO NORTE DO PARANÁ ${ }^{266}$}

\section{OCORRÊNCIAS DE GEADAS E SUA EXPANSÃO ESPACIAL}

Um dos problemas mais graves da economia do café no Paraná é o fato de que a migração do cultivo do café para o sudoeste e para o sul conduziu a um avanço para a área do limite climático do café, isto é, em regiões ameaçadas pela geada. As plantações de café se estendem para além do trópico, até a latitude de $24^{\circ} 30^{\prime}$ S. O Norte do Paraná é com isso a região cafeeira significativa mais meridional do planeta ${ }^{267}$. As áreas de rendimentos mais altos apresentam, contudo, devido aos danos causados pela geada, oscilações de produção fora do comum, cujos efeitos provocavam uma forte instabilidade da oferta, e com isso do preço do café, não só nacionalmente como também no mercado cafeeiro internacional.

Geadas noturnas podem se manifestar na região de cultivo de café no Norte do Paraná entre o começo de junho e o começo de setembro. Excetuando-se as raras geadas no Norte do Paraná causadas por fortes radiações noturnas, são temidas especialmente as ondas de frio provenientes do sul, pois podem provocar danos graves nas plantações sensíveis à geada (como os Northers na América do Norte e América Central). De maio a setembro, as frentes frias de massas polares do Atlântico advindas do sul e do sudoeste alcançam sua maior intensidade e avançam para as planícies baixas da bacia do ParanáParaguai e na região costeira mais ao norte, onde suas consequências devido à forte diminuição de temperaturas são sentidas como 'friagens' até o Mato Grosso e o Acre (até $8^{\circ}$ de latitude sul!), bem como na região costeira da Bahia e inclusive até o Recife.

A aproximação de uma frente fria é anunciada por ventos predominantes do norte e noroeste e por um aquecimento abrupto causado por uma troca rápida da direção do vento. O 'Pampero' gelado e seco e sua continuação no Brasil, o 'Minuano', trazem consigo uma frente fria do sudoeste, que se afasta sob as correntes de ar tropicais quentes e úmidas, e, devido à convecção, trazem consigo pancadas de chuvas torrenciais antes da frente, que muitas vezes estão ligadas a tempestades.

Depois da instabilidade temporária das condições meteorológicas, que está relacionada com o avanço da frente fria, a frente fria entra com o desanuviamento e causa frequentemente uma queda de temperatura de mais de $20^{\circ} \mathrm{C}$; com isso, é comum ocorrer geadas (IBG, 1968, T. 1, p. 133ss.). Por causa da influência das correntes de ar tropicais do Atlântico, a frente fria se desloca geralmente na direção ONO-ESE.

A duração total das intrusões de ar frio depende da intensidade da acumulação de correntes de ar polares na Patagônia e da intensidade do avanço de anticiclones. Em geral, o processo completo dura cerca de uma semana, até a mínima diária voltar a se estabilizar em valores médios. Geadas ocorrem, todavia, geralmente em apenas um ou raramente em dois desses dias (igura 7A).

Com isso, a temperatura cai rapidamente depois do desanuviamento no final da tarde ou no início da noite e alcança, por volta das 6 horas, pouco antes do nascer do sol, o seu mínimo absoluto, para subir de novo abruptamente. Com isso, a geada com frequência dura apenas poucas horas (Figura 7B), que são suficientes para causar prejuízos às plantações de culturas sensíveis a ela. Se até as $22 \mathrm{~h}$ a temperatura cair para menos de $10^{\circ} \mathrm{C}$, então os danos causados pela geada nas plantações de café são esperados, em geral, nas primeiras horas da manhã do dia seguinte.

266 Tradução de Dionei Mathias e Natasha Pereira da Silva.

267 Algumas plantações de café em regiões altas favoráveis (580-600 m) e regiões de declive ao norte chegavam, ao sudoeste de Cascavel (Céu Azul), até mais de $25^{\circ} \mathrm{S}$; contudo, elas produziam apenas produtos pouco significativos e eram, em parte, abandonadas. - Nas terras baixas costeiras livres de geada em Santa Catarina, cultivava-se café nos quintais de casa sob árvores de sombra em forma de sebe para o abastecimento próprio, inclusive até $27^{\circ} \mathrm{S}$. 
Figura 7: Relações de temperatura com a entrada da frente fria no Norte do Paraná

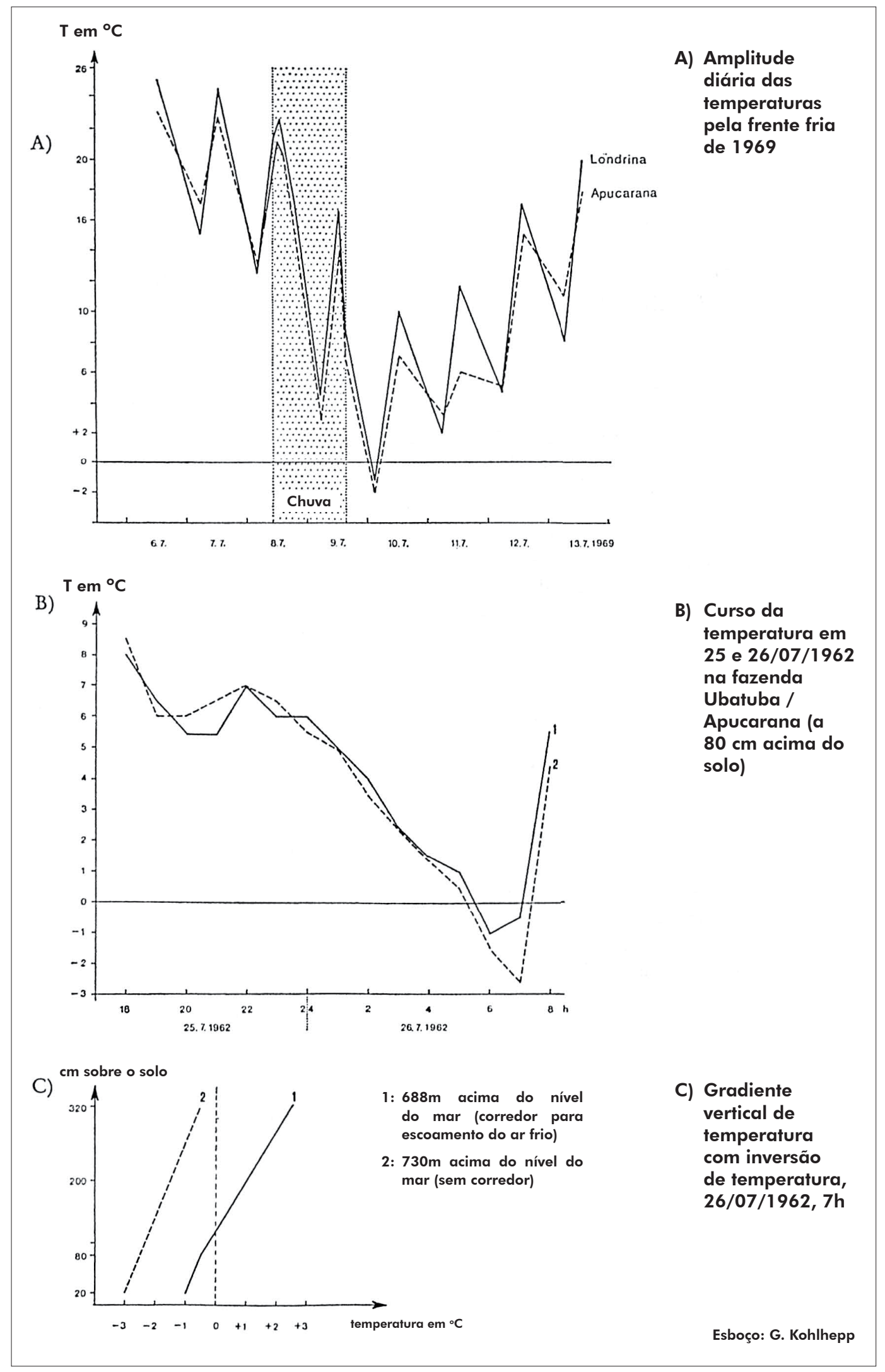

Fontes: A) Anderson, Clayton Co.; B) e C) Ortolani et al., 1963. 
Devido à distribuição irregular das estações de observação meteorológica à falta de dados das áreas pioneiras do Oeste, a frequência das geadas pode ser constatada cartograficamente apenas de maneira parcial. O Mapa 5 mostra a quantidade média anual de dias com geada, onde naturalmente é constatada - com exceção das regiões isoladas de elevada altitude no Planalto Meridional, com geadas anuais e uma grande frequência de geadas - uma contínua diminuição do número de dias de geada por ano em direção norte. A região do cultivo de café no Norte do Paraná vivencia em média de 2 a 4 geadas a cada dez anos (MAACK, 1968, p. 102). Nesse contexto, deve-se salientar que a ocorrência de geadas no Norte do Paraná aumentou muito na última década. Isso deve ser atribuído ao livre avanço dos ventos frios do sul devido à devastação excessiva das florestas subtropicais do Paraná (MAACK, 1956 e 1960b).

Até então, nas regiões cafeeiras no Norte do Paraná haviam sido registradas ${ }^{268}$ as fortes geadas a seguir, como a forte geada de 1918, que provocou enormes danos sobretudo nas plantações de café em São Paulo - já que a colonização no Paraná a oeste do Rio Tibagi ainda não havia começado:

Tabela 33: Prejuízos da geada no cultivo de café

\begin{tabular}{|l|l|l|}
\hline 1918 & 25 de junho & São Paulo \\
\hline 1942 & Final de junho, 7 de julho, 14 de julho & Paraná/São Paulo \\
\hline 1953 & 4 de julho & Paraná \\
\hline 1955 & 31 de julho & Paraná/São Paulo (Região de Marília) \\
\hline 1962 & Início de junho & Paraná \\
\hline 1963 & 6 de julho & Paraná \\
\hline 1966 & 5 de agosto & Paraná \\
\hline 1967 & início de agosto & Paraná \\
\hline 1969 & 9 de julho & Paraná/São Paulo (Marília) \\
\hline
\end{tabular}

Fonte: ver nota 3.

A distribuição temporal das geadas mostra que o período crítico tem a duração de cerca de 8 semanas do início de junho ao início de agosto. O mês de julho apresenta a maioria das geadas e também as temperaturas absolutas mais baixas. No Norte do Paraná, segundo Maack (1968, p. 100-101), ocorrem regularmente geadas acima de $800 \mathrm{~m}$ acima do nível do mar; no entanto, o limite inferior absoluto da ocorrência das geadas fica entre 350 e $450 \mathrm{~m}$. Abaixo dessa altitude, porém, apenas pequenas áreas são apropriadas para o cultivo do café, devido ao tipo de solo e ao perigo de inundação na região de influência dos grandes rios.

Enquanto as geadas de radiação tinham consequências apenas regionais e locais, as ondas fortes de frio manifestavam-se em todo Norte do Paraná e também em parte de São Paulo. A chegada da geada durante a madrugada de 30 a 31 de julho de 1955 representou, na região entre Apucarana e Maringá, temperaturas extremamente baixas, entre $-5^{\circ} \mathrm{C}$ e $-9^{\circ} \mathrm{C}$, principalmente nos vales. Em Apucarana $(870 \mathrm{~m})$, a temperatura caiu para $-2,5^{\circ} \mathrm{C}$, enquanto que nos vales caiu até $-8,5^{\circ} \mathrm{C}$ (MAACK, 1968, p. 104).

A paisagem agrária foi decididamente marcada pelo fato de o ar frio descer para os vales e com isso causar inversões de temperatura. As plantações de café se expandem pelas encostas elevadas dos espigões e ocupam somente as partes superiores das encostas dos vales. O escoamento do ar frio mantém livres de geadas as partes localizadas mais alto, enquanto na área de encosta ocorrem graves danos, ainda mais porque os pequenos cursos d'água, devido à baixa condensação, não conseguem manter os fundos de vale livres de geada por meio da formação de nevoeiros (Fotos 5 e 9).

Medições em Rolândia mostraram que a diferença de temperatura no ponto mais baixo de uma plantação de café ficava de $3^{\circ} \mathrm{C}$ a $4^{\circ} \mathrm{C}$ abaixo da temperatura mínima do ponto mais alto (espigão), com somente $160 \mathrm{~m}$ de diferença de altitude ${ }^{269}$. Isso é confirmado por medições de temperatura nas cidades

268 Compilação segundo informações do Instituto Brasileiro do Café e da empresa Anderson, Clayton \& Co., S/A, bem como reportagens e documentação particular.

269 Informações gentilmente cedidas pelo Sr. Rosenthal da fazenda Nova Breesen, Rolândia. Medições na altitude de $550 \mathrm{~m}-710 \mathrm{~m}$ a $50 \mathrm{~cm}$ do chão. 
localizadas nos espigões, nas quais, entre 1966 e 1970, as temperaturas só muito raramente chegaram a menos de $+5^{\circ} \mathrm{C}$ e só excepcionalmente ocorreram geadas (Tabela 34).

Em 9/10 de julho de 1969 foram registradas geadas em quase todo o norte do Paraná, com intensidades muito variadas regionalmente. Os dados de temperatura variavam, dependendo da altitude, da exposição da encosta e da localização das estações, entre $\pm 0^{\circ} \mathrm{C}$ e $-4^{\circ} \mathrm{C}^{270}$.

As consequências dos danos foram intensificadas em 1969 devido aos gelados ventos do sul. Os municípios mais afetados foram os localizados no sudeste da região estudada, sobretudo Faxinal, Califórnia, Grandes Rios, Bom Sucesso e Marilândia do Sul. As encostas sul ficaram especialmente expostas a esses ventos, de modo que se registrou ali uma perda total das plantações de café devido à geada.

No ano de 1969, a combinação de geada de vento e geada de radiação não ocorreu somente na periferia sul da região de cultivo de café, mas também na fronteira entre Paraná e São Paulo, como por exemplo no município de Porecatu. Uma pesquisa com os membros da cooperativa local mostrou que as plantações de café expostas mais elevadas apresentavam, pela ação do vento, danos devidos à geada já a partir do final da tarde do dia 9/7/1969, enquanto que, em 10 de julho cedo pela manhã, a geada de radiação e o acúmulo do ar frio correspondente eliminaram as plantações nas encostas mais baixas. ${ }^{271 .}$

Tabela 34: Quantidade de dias com temperatura mínima abaixo de $5^{\circ} \mathrm{C}$ por ano (Ø 1966-1970)

\begin{tabular}{|c|c|c|c|c|c|c|c|}
\hline Estação & $\begin{array}{l}\text { m acima do } \\
\text { nível do mar }\end{array}$ & Maio & Junho & Julho & Agosto & \multicolumn{2}{|c|}{ Total } \\
\hline \multirow[b]{2}{*}{ Londrina } & \multirow[b]{2}{*}{ (610) } & \multirow[b]{2}{*}{0,4} & \multirow[b]{2}{*}{0,4} & \multirow[b]{2}{*}{0,8} & \multirow[b]{2}{*}{0,2} & \multicolumn{2}{|c|}{1,8 dias } \\
\hline & & & & & & Mín $-1^{\circ} \mathrm{C}$ & Geadas: 1 dia \\
\hline \multirow[b]{2}{*}{ Apucarana } & \multirow[b]{2}{*}{ (870) } & \multirow[b]{2}{*}{0,6} & \multirow[b]{2}{*}{0,4} & \multirow[b]{2}{*}{0,6} & \multirow[b]{2}{*}{0,4} & \multicolumn{2}{|c|}{ 2,0 dias } \\
\hline & & & & & & Mín $-2^{\circ} \mathrm{C}$ & Geadas: 1 dia \\
\hline \multirow[b]{2}{*}{ Maringá } & \multirow[b]{2}{*}{ (556) } & \multirow[b]{2}{*}{0,2} & \multirow[b]{2}{*}{0,8} & \multirow[b]{2}{*}{0,8} & \multirow[b]{2}{*}{0,2} & \multicolumn{2}{|c|}{ 2,0 dias } \\
\hline & & & & & & Mín $0^{\circ} \mathrm{C}$ & Geadas: - \\
\hline \multirow[b]{2}{*}{ Paranavaí } & \multirow[b]{2}{*}{ (508) } & \multirow[b]{2}{*}{-} & \multirow[b]{2}{*}{0,2} & \multirow[b]{2}{*}{0,6} & \multirow[b]{2}{*}{0,6} & \multicolumn{2}{|c|}{1,4 dias } \\
\hline & & & & & & Mín $0^{\circ} \mathrm{C}$ & Geadas: - \\
\hline \multirow[b]{2}{*}{ Cruzeiro do Oeste } & \multirow[b]{2}{*}{$(580)$} & \multirow[b]{2}{*}{0,2} & \multirow[b]{2}{*}{0,2} & \multirow[b]{2}{*}{0,8} & \multirow[b]{2}{*}{0,4} & \multicolumn{2}{|c|}{1,6 dias } \\
\hline & & & & & & Mín $0^{\circ} \mathrm{C}$ & Geadas: - \\
\hline$\varnothing$ (média) & & 0,3 & 0,4 & 0,7 & 0,4 & \multicolumn{2}{|c|}{1,8 dias } \\
\hline
\end{tabular}

Fonte: Análise, pelo Autor, das observações climáticas das filiais da empresa Anderson, Clayton \& Co., S./A., 1966 a setembro de 1970.

Em áreas com maiores diferenças de relevo, pode-se reconhecer as linhas de drenagem do ar frio descendente na composição da vegetação. A palmeira icara (Euterpe edulis), sensível à geada e encontrada largamente nas florestas tropicais até o subtrópico, é cada vez menos frequente nos vales. No seu lugar aparece a palmeira jerivá (Arecastrum romanzoffianum), que desaparece somente com mais de 15 dias de geada ao ano (MAACK, 1948, p. 127). Nas encostas sul e nos vales profundamente encravados, surgem também na floresta exemplares da Araucaria angustifolia, que é resistente a geadas e permanece, nos canais de escoamento, abaixo do seu limite inferior de propagação, em geral estabelecido em cerca de 500m acima do nível do mar. Um exemplo semelhante oferece o Rio Cambé, ao sul do espigão entre Arapongas e Londrina. Depois de a geada causar danos, já em 1933,

270 Dados da companhia aérea Varig, da empresa Anderson, Clayton \& Co., S./A., bem como as medições privadas foram utilizados para a comparação.

271 Fotografias particulares dos cafezais do Sítio Santo Antonio do Sr. E. Frassato já mostravam, em 9/7/1969 às 16 horas, a coloração escura da folhagem dos cafeeiros. Popularmente fala-se em geada de vento, por isso fala-se em geada preta, ao contrário da geada branca, com geada de radiação com formação de gelo sobre as plantas (cf. Cap. II, 2). No último caso aparecem os grandes prejuízos somente com menos de $-2^{\circ} \mathrm{C}$. (CAMARGO 1960; 1966, bem como informações fornecidas oralmente por agrônomos do IBC). 
às plantações de café feitas em 1932 - danos esses que se repetiram de maneira catastrófica em 1942 e 1948 - , as plantações de café localizadas na região do vale foram abandonadas. Por outro lado, os cafeeiros situados no cume não registraram danos causados pela geada por um período de 15 a 18 anos (MAACK, 1968, p. 99-100).

$\mathrm{Na}$ exploração das regiões de florestas tropicais foi especialmente registrado, pelos agrimensores e compradores de terras - ao lado de indicadores de bons solos -, a existência de Euterpe edulis como sinal de ausência de geada; depois, foi feita a escolha da terra prevista para plantações de café. Até a papaya selvagem (Jaracatia dodecaphylla), extremamente sensível à geada, servia de planta dominante na vegetação natural, já que as perturbações de crescimento dessas plantas provocadas pela geada ficam visíveis por muito tempo (SCHRÖDER, 1956, p. 132).

Os desmatamentos extensivos provocaram, contudo, grandes distúrbios no equilíbrio natural do calor e da umidade naturalmente válidos para a floresta tropical. Em especial, ocorriam cada vez com mais frequência maiores amplitudes diárias e temperaturas extremas.

Na região cafeeira do Norte do Paraná há sempre muita tensão na população durante a estação do ano no qual há o risco de geada. Os fortes danos frequentemente ameaçam a existência de pequenos e médios proprietários. Para as grandes fazendas, eles significam perdas de lucro enormes ${ }^{272}$ ou necessitam de grandes investimentos para o novo plantio etc. Além dos proprietários de terras, arrendatários, administradores envolvidos proporcionalmente na colheita, trabalhadores rurais e trabalhadores migratórios, os 'maquinistas' - que executam o preparo do café -, organizações de comercialização, filiais das empresas exportadoras de café, empresas de transporte, atacado e varejo, indústrias produtoras de adubos e também os bancos temem os efeitos sobres seus lucros. Depois de fortes geadas, os investimentos em todos os setores caem bastante, e até a próxima floração predomina uma incerteza - que em geral paralisa qualquer atividade econômica normal - sobre a extensão dos danos causados pela geada.

Reportagens de jornal sobre relatos de geadas oriundas do Uruguai e do Rio Grande do Sul, bem como do Planalto Meridional, e consequentemente sobre a aproximação de frentes frias são acompanhadas com preocupação. Embora ainda não exista, neste início dos anos 1970, um serviço organizado de alerta contra geadas, as filiais das empresas exportadoras de café, os escritórios locais de empresas aéreas e as poucas estações de observação meteorológicas oficiais do Ministério da Agricultura repassam alertas contra perigos de geada por meio das estações de rádio locais que alcançam a uma parte dos plantadores de café.

\section{MÉTODOS PARA IMPEDIR DANOS CAUSADOS PELA GEADA NO PLANTIO DE CAFÉ}

Em face da extensão dos danos, foram feitas tentativas, há muito tempo, por parte do setor privado - e também do setor público através do IBC e do Instituto Agronômico em Campinas-SP - de desenvolver métodos para impedir os danos causados pelas geadas. ${ }^{273}$ Recorreu-se a experiências norteamericanas com plantações cítricas ameaçadas por geadas na Califórnia e na Flórida, bem como também a experimentos aplicados nas regiões vinícolas alemãs.

\section{a) Medidas preventivas}

Com base na experiência anterior com danos causados por geada, foram executadas medidas preventivas referentes à posição e exposição de inclinação das plantações de café. Por conseguinte, os cafeeiros situados numa área com maior acúmulo de ar frio foram arrancados, por exemplo, em depressões e no terço inferior da encosta, como também nos canais de escoamento de ar frio emanante da região da fonte de pequenos córregos até a base do vale.

272 Assim, as perdas totais de uma fazenda perto de Apucarana com aproximadamente 450.000 cafeeiros em decorrência da geada em 1969 foram calculadas em um valor superior a 1 milhão de dólares (de acordo com informações gentilmente cedidas pela Fazenda Ubatuba, em 25 de setembro de 1970).

273 No Paraná, a Secretaria de Agricultura do estado fundou um "Serviço de estudos para a defesa contra a geada". 
Devido ao perigo de inversões térmicas no inverno, as plantações de café se estendem ao longo de espigões, frequentemente com restos de mata na área inferior da encosta, sobretudo em plantações maiores. O acúmulo de ar frio no limite superior da mata causou, em parte, prejuízos significantes, de maneira que foram abertos aceiros na mata, em pequenos vales íngremes para o escoamento do ar frio.

O Mapa 32 mostra uma comparação dos danos causados pela geada de 1955 e 1962 numa parte de uma fazenda de café perto de Apucarana. Lá fica especialmente clara a importância dos 100 - $150 \mathrm{~m}$ de largura para o escoamento de ar frio e, consequentemente, para a prevenção de danos de geada $(1962,1)$, enquanto os danos causados por geada em 2 ficaram constantes.

O efeito do corredor estabelecido pode ser comprovado também por meio de uma medição comparativa de temperatura (Mapa 32 e Figura 7B, C). O ar frio que escoa rapidamente deixa a temperatura no ponto mais baixo 1 cair quase $2^{\circ} \mathrm{C}$ apesar da inversão térmica. ${ }^{274} \mathrm{O}$ ponto 2 , por outro lado, continua indicando um acúmulo de ar frio. Essa diferença aparece também nos dois pontos, ao observar-se os gradientes de temperatura verticais (Figura 7C). A $20 \mathrm{~cm}$ acima do solo, a diferença é de $2^{\circ} \mathrm{C}$ (no ponto $1:-1^{\circ} \mathrm{C}$; no ponto $2:-3^{\circ} \mathrm{C}$ ), a uma altura de $3,20 \mathrm{~m}$ até mesmo $3^{\circ} \mathrm{C}\left(1:+2,5^{\circ} \mathrm{C} ; 2:-0,5^{\circ} \mathrm{C}\right.$ ). O escoamento rápido de ar frio, em ponto 1 , faz com que numa altura de pouco mais de $1 \mathrm{~m}$ já não haja mais geada.

Por razões climáticas, plantios de café em encostas com uma inclinação superior a 10\% são especialmente favorecidos, já que aqui o ar frio escoa mais rapidamente. Por outro lado, plantações situadas em depressões localizadas em planaltos são mais intensamente ameaçadas por geadas.

Entre as medidas preventivas microclimaticamente importantes está o capinar entre as fileiras de cafeeiros para um melhor arejamento das plantações. Em noites de geada, os cafeeiros tenros têm de ser cobertos com palha, no buraco de plantio.

\section{b) Combate direto à geada}

Para o combate direto à geada na noite, foram empregados até aquele momento o aquecimento do ar por meio de disposição de fornos a óleo, de circulação de ar através de grandes ventiladores, do borrifamento (chuvisco artificial) e da nebulização.

Em face da grande extensão das plantações de café, seja na forma de latifúndios isolados ou de muitas fazendas de pequeno e médio porte, e por causa dos investimentos excepcionalmente altos necessários para a instalação das respectivas aparelhagens e sua manutenção, as medidas de combate direto à geada só foram executados esporadicamente. Nisso a nebulização se afirmou, por causa dos baixos custos ${ }^{275}$ e das condições de relevo, como a única solução recomendável para o Norte do Paraná, por motivos práticos e econômicos. ${ }^{276}$ Especialmente importantes, no entanto, são o modo de nebulização (combustão de cápsulas de fumaça ou pulverização), a técnica correta da aplicação e momento adequado da execução. A nebulização tem de ser iniciada quando é alcançada uma temperatura de $+2^{\circ} \mathrm{C}$ a $50 \mathrm{~cm}$ acima do solo, antes das 4 da madrugada, pois então deve-se temer uma queda para $-2^{\circ} \mathrm{C}$ até o nascer do sol, a temperatura-limite para a aparição de prejuízos maiores nas plantações de café. Preparativos planejados são necessários para a execução da nebulização em noites de geada por empregados capacitados.

A nebulização, que tem a função de impedir o acúmulo de ar frio sobre o solo, é melhor executada em diferentes pontos na parte superior da encosta. O método é especialmente apropriado para depressões e pequenas bacias de vales cuja área não ultrapasse 250 ha (CAMARGO, 1960, p. 18ss.).

274 Cf. sobre isso uma reportagem de Camargo (1959) sobre tentativas práticas de combate à geada, na Fazenda Stinnes em Ubatuba, perto de Apucarana, como também Ortolani, Camargo e Salati 1963. - A mudança das condições de temperatura na Figura 7B, em 25 de julho de 1962, antes das 24h, tem de ser atribuída à ação do vento, que somente diminuiu na madrugada.

275 Tentativas realizadas pelo Instituto Agronômico em Campinas-SP e no Paraná mostraram que os custos do aquecimento do ar com aparelhagens de combustão de óleo chegavam a 50 vezes o valor da nebulização (CAMARGO 1960, p. 11/12; 1966, p. 17ss.).

276 Aparelhagens para borrifamento de chuvisco artificial sobre plantas e, com isso, para formação artificial de escarcha como medida de proteção contra geadas de irradiação rigorosas foram instaladas a título de experiência em algumas plantações, mas, pelo autor, só puderam ser observadas em funcionamento em 1970 no Planalto de Amambay no leste do Paraguai, ao sul de Pedro Juan Caballero. 
Êxito, no entanto, só pode ser alcançado quando se trata de geadas de irradiação, pois a nebulização localizada somente é possível com calmaria completa.

Enquanto até agora somente fazendas de médio e grande porte levantaram o capital para um combate ativo à geada, há planos para realizar um combate direto à geada no setor de pequenas propriedades, em partes relativamente estreitas, numa base cooperativa.

O acúmulo de geadas com consequências econômicas graves na década de 1960 aumentou a disposição geral dos plantadores para experimentos com o propósito de combater a geada. As dúvidas sobre a eficácia das medidas em áreas grandes, no entanto, permaneceram, especialmente quando a névoa artificial é movida para baixo pela ação do vento, em direção ao vale.

O fato empírico de que com cafeeiros bem adubados e saudáveis se registrava, em geral, relativamente pouca perda de colheita devido a danos causados pela geada garantiu à indústria de fertilizantes um forte aumento de vendas nos 4 anos anteriores à conclusão desta pesquisa.

\section{ANÁLISE QUANTITATIVA DOS DANOS CAUSADOS PELA GEADA EM 1969}

Se algumas das ocorrências mais fracas de geada no passado, durante o boom do plantio de café no Norte do Paraná, tiveram um efeito que freou o aumento excessivo de produção - consequentemente, um efeito positivo - , a última geada de 1969 atingiu a economia cafeeira do Paraná numa fase de consolidação, após a finalização das diferentes medidas de restrição ao plantio. Os danos causados pela geada de 10 de julho de 1969 foram os mais amplos registrados até agora em sua extensão, incluindo todo o Norte do Paraná (Foto 15).

A dimensão das geadas e, com isso, as perdas de colheita são classificadas pelo Instituto Brasileiro do Café em três níveis de intensidade, de acordo com o seguinte esquema:

a) O congelamento das folhas e dos ramos medianos do cafeeiro até um terço do comprimento do ramo. Isso significa, em geral, a perda de uma colheita, ou seja, da colheita do ano seguinte.

b) Morte das folhas e dos ramos (até dois terços): Perda da colheita dos dois anos seguintes.

c) Morte das folhas, dos ramos e do tronco: Perda de 3 colheitas ou, em caso de morte completa, perda total. Isto torna necessário erradicar o cafeeiro ou podá-lo até cerca de $30-40 \mathrm{~cm}$ acima do solo.

A Tabela 35 dá uma ideia da intensidade e da extensão dos danos causados pela geada nos últimos 10 anos no Paraná.

Enquanto em 1962 somente um terço e, em 1963, dois terços dos cafeeiros sofreram danos causados pela geada, em 1969 quase todos os cafeeiros do Norte do Paraná (97\%) foram atingidos. 42\% revelaram danos leves causados pela geada, 33\% medianos e 22\% fortes. Uma comparação da distribuição de frequência da intensidade da geada mostra que, no ano da geada de 1963, houve a maior concentração de danos graves, com $38 \%$, enquanto, em 1969, puderam ser registrados danos fracos com maior frequência $(42 \%) .^{277}$

A diferenciação regional da intensidade dos danos causados pela geada ${ }^{278}$ na região de plantio de café do Norte do Paraná é mostrada no Mapa 33. Houve fortes danos causados pela geada na região do médio Ivaí e do Rio Pirapó, onde foram registrados danos graves nas plantações de café localizadas no declive inferior da encosta e nos vales fluviais, em decorrência de inversões de temperatura e acúmulo de ar frio. Nos municípios de Flórida, Lobato, Paiçandu, Floresta, Doutor Camargo e Ivatabu, mais de $75 \%$ dos cafeeiros apresentam fortes danos causados pela geada e, com isso, provavelmente uma perda de colheita de três anos. Também as partes mais baixas dos

277 Para comparação: em 1953 houve danos causados pela geada em 72\% dos cafeeiros (37\% danos fortes, 35\% fracos); em 1955, houve danos causados pela geada em 36\% (MAACK, 1968, p. 132).

278 Avaliação, pelo Autor, da análise aleatória por parte dos agrônomos do IBC/Gerca, usando o método Tschuproff-Neyman, e dos relatórios para as áreas SAG individuais (área de trabalho de um agrônomo), por município. Coleta de material nas agências regionais do IBC em Londrina e Maringá, bem como no Departamento Estadual do Café, Escola de Agronomia (Projeto Cerena) e Faep em Curitiba. 
municípios de Terra Boa até Rondon, localizados ao sul do Ivaí, foram gravemente atingidas, e até mesmo as plantações situadas na região dos espigões entre o Ivaí e o Pirapó numa altitude de aproximadamente $500 \mathrm{~m}$ sofreram perdas significativas por conta dos gelados ventos meridionais. Sobretudo houve somente danos fracos a medianos ou medianos nas regiões elevadas de plantio em volta de Apucarana e na cumeada até Londrina, ou seja, na área dos divisores de água Pirapó/ Bandeirantes e Ivaí/Tibagi.

Tabela 35: Intensidade e extensão de danos causados pela geada em plantações de café no Norte do Paraná

\begin{tabular}{|c|c|c|c|c|c|}
\hline \multirow{3}{*}{ Intensidade da geada } & \multirow{3}{*}{ Perda de colheita em anos } & \multicolumn{4}{|c|}{ Danos causados pela geada } \\
\hline & & 1962 & 1963 & 1966 & 1969 \\
\hline & & \multicolumn{4}{|c|}{ em \% do número total } \\
\hline Nível a (fraco) & 1 & 12 & 13 & 22 & 42 \\
\hline Nível b (mediano) & 2 & 10 & 15 & 20 & 33 \\
\hline Nível c (forte) & 3 & 11 & 38 & 15 & 22 \\
\hline \multicolumn{2}{|c|}{ Total de cafeeiros com danos causados pela geada } & 33 & 66 & 57 & 97 \\
\hline
\end{tabular}

Fonte: Dados fornecidos pelo IBC e Gerca (1969).

As plantações de café pouco extensas, situadas na Serra do Cantu, a sudoeste da região de análise, entre Mamborê e Goio-Erê, sofreram relativamente poucos danos por causa da inversão de temperatura de julho de 1969.

Do Mapa 33 pode-se inferir que a influência da geada diminui em direção ao Nordeste. Na região em volta de Cambé e Sertanópolis, em parte 20-30\% dos cafeeiros não apresentam danos significativos causados pela geada. Isso é confirmado no Norte Velho, no Nordeste do Paraná - localizado fora da região estudada - , onde, em contraste evidente com o restante do Norte do Paraná, $14 \%$ dos cafeeiros não foram atingidos pela geada e somente $9 \%$ foram danificados gravemente.

No panorama regional, resultaram os seguintes danos causados pela geada em 1969, no plantio de café paranaense ${ }^{279}$ (ver Tabela 36).

Enquanto os efeitos negativos da geada (cerca de 10\%) foram pequenos sobre a colheita de café em julho de 1969, - cerca de 9\% dos frutos já estavam maduros de acordo com IBC ${ }^{280}$ —, os danos na colheita do ano de 1970 são estimadas em $81 \%$.

As plantações de café de um a 2 anos foram, em parte, mais fortemente danificadas do que é mostrado na Tabela 37 no grupo de até 4 anos.

279 Empregada para fins de comparação, a avaliação de um levantamento da representação regional da firma norte-americana Anderson Clayton \& Co, em Londrina e Maringá, mostrou cotas percentuais similares de danos causados pela geada, para o ano de 1969, usando também uma diferenciação de intensidade tripartida, em nível municipal.

Nisso, somente o Norte Novíssimo II representa uma exceção, ou seja, as regiões ao sul do Ivaí, onde foram constatados danos fortes em $26 \%$ dos cafeeiros, em contraste com os dados do IBC (18\%). Agradeço aqui pela autorização para a verificação dos levantamentos de uso interno da empresa.

280 Somente os grãos de café verdes e não maduros ressecam em consequência da geada, ficando pretos. Por esse motivo, chamam-se de queimados os cafeeiros que sofreram danos causados pela geada. Os grãos pretos da colheita têm um efeito negativo na qualidade do sabor. 
Tabela 36: Danos causados pela geada no plantio de café no Paraná em 10 de julho de 1969 (em 1000 cafeeiros)

\begin{tabular}{|c|c|c|c|c|c|c|c|c|c|c|c|c|}
\hline \multirow{3}{*}{ Região } & \multicolumn{8}{|c|}{ Danos causados pela geada em cafeeiros } & \multirow{2}{*}{\multicolumn{2}{|c|}{$\begin{array}{l}\text { Sem danos } \\
\text { causados por } \\
\text { geada }\end{array}$}} & \multirow{2}{*}{\multicolumn{2}{|c|}{$\begin{array}{l}\text { Qtd. total } \\
\text { cafeeiros }\end{array}$}} \\
\hline & \multicolumn{2}{|c|}{ fraco } & \multicolumn{2}{|c|}{ mediano } & \multicolumn{2}{|c|}{ forte } & \multicolumn{2}{|c|}{ total } & & & & \\
\hline & Qtd. & $\%$ & Qtd. & $\%$ & Qtd. & $\%$ & Qtd. & $\%$ & Qtd. & $\%$ & Qtd. & $\%$ \\
\hline Norte Novo & 129212 & 41 & 91032 & 29 & 83255 & 26 & 303499 & 96 & 10511 & 4 & 314010 & 37 \\
\hline \multicolumn{13}{|l|}{ Norte Novíssimo I } \\
\hline (Região Paranavaí) & 91131 & 41 & 73717 & 33 & 54673 & 25 & 219521 & 99 & 1935 & 1 & 221456 & 26 \\
\hline $\begin{array}{l}\text { Norte Novíssimo II } \\
\text { (Reg. Umuarama e } \\
\text { Campo Mourão) }\end{array}$ & 93869 & 44 & 77760 & 37 & 38814 & 18 & 210443 & 99 & 1013 & 1 & 211456 & 25 \\
\hline Norte Velho & 43165 & 43 & 34730 & 34 & 9355 & 9 & 87250 & 86 & 13494 & 14 & 100744 & 12 \\
\hline Paraná total & 357375 & 42 & 277239 & 33 & 186097 & 22 & 820713 & 97 & 26953 & 3 & 847666 & 100 \\
\hline
\end{tabular}

Fonte: Gerca, 1969.

Tabela 37: Danos causados pela geada em 1969 nas plantações de café, no Norte do Paraná, de acordo com a idade e a situação de produção dos cafeeiros

\begin{tabular}{|l|c|c|c|c|c|c|}
\hline & \multicolumn{3}{|c|}{$\begin{array}{c}\text { Danos causados pela geada } \\
\text { Intensidade da geada }\end{array}$} & \multicolumn{3}{c}{ Total de cafeeiros } \\
\hline $\begin{array}{l}\text { Cafeeiros } \\
\text { Idade e estágio de produtividade }\end{array}$ & $\begin{array}{c}\text { leve } \\
\%\end{array}$ & $\begin{array}{c}\text { médio } \\
\%\end{array}$ & $\begin{array}{c}\text { forte } \\
\%\end{array}$ & $\begin{array}{c}\text { Total } \\
\%\end{array}$ & Quant. & $\%$ do total do Paraná \\
\hline Até 4 anos (ainda não produzindo) & 28 & 36 & 28 & 92 & 49.199 & 5,8 \\
\hline Mais de 4 anos (produzindo) & 44 & 32 & 21 & 97 & 775.730 & 91,5 \\
\hline Mais de 4 anos (não produzindo) & 26 & 21 & 53 & 100 & 22.737 & 2,7 \\
\hline Paraná & 42 & 33 & 22 & 97 & 847.666 & 100,0 \\
\hline
\end{tabular}

Fonte: Gerca, 1969b.

Tabela 38: Retrocesso de produção no plantio de café no Paraná, após a ocorrência de geadas

\begin{tabular}{|c|c|c|c|}
\hline \multirow[t]{2}{*}{ Ano da geada } & \multicolumn{2}{|c|}{$\begin{array}{c}\text { Produção de café } \\
\text { (em } 1000 \text { sacas } 60 \text { kg) }\end{array}$} & \multirow{2}{*}{ Retrocesso de produção em \% } \\
\hline & no ano da geada & no ano seguinte & \\
\hline 1953 & 3.198 & 1.337 & 58 \\
\hline 1955 & 6.306 & 2.178 & 65 \\
\hline 1962 & 18.032 & 9.157 & 49 \\
\hline 1963 & 9.157 & 7.146 & 22 \\
\hline 1969 & $8.500^{*}$ & $1.600^{*}$ & 81 \\
\hline
\end{tabular}

* Última estimativa de colheita do IBC (de acordo com: Anuário Estatístico do Café 1972)

Fonte: 1953-1963: IBC-Divisão de Estatística, informações pessoais.

No entanto, a influência das novas plantações atingidas sobre a tendência de desenvolvimento da produção de café nos próximos anos é relativamente baixa, já que sua porcentagem no total de cafeeiros é menor que $6 \%$ e, com isso, uma perda total também não será de importância decisiva. Com a morte completa das plantas jovens mais vulneráveis à geada por terem menor proteção pelas folhas, contudo, investimentos maiores se fazem necessários para plantios novos, estendendo o período não-produtivo até mais de quatro anos, até o alcance da idade produtiva das árvores. 
As perdas de produção no ano de colheita após os danos causados pela geada alcançaram, antes do ano de 1969, o seu máximo com 65\%, levando em consideração a geada forte de 1955 (Tabela 38). Sobre a geada extremamente forte de 1942 não há dados relativos à provável perda de produção. No Paraná, o plantio de café, no entanto, encontrava-se nessa época somente em fase inicial, de maneira que pelo menos as perdas absolutas foram baixas.

No entanto, é necessário relativizar os dados do IBC e rever sua expressividade e suas consequências efetivas. Para a perda da colheita é decisivo se a geada cai num período 'alto' ou 'baixo', durante o ritmo produtivo bianual de colheitas boas e ruins (Figuras 2 e 14).

No primeiro caso, teria de ser esperar de qualquer modo uma colheita mais fraca no ano seguinte, de maneira que o retrocesso de produção, aumentado pelos danos causados pela geada, é de fato muito alto, mas a perda propriamente dita pode ser muito mais baixa (por exemplo em 1955/56).

Se, contudo, a geada surge num ano com uma colheita pequena, ou seja, numa fase de regeneração dos cafeeiros, então a perda da colheita do ano seguinte, no qual era de se esperar uma colheita boa, é relativamente maior, embora a produção absoluta comparada com o ano de geada pode aumentar levemente (Figuras 2 e 14).

Na redução de produção, a geada de 1969 excedeu mais ainda o retrocesso de 1955 para 1956, em relação à colheita seguinte, do ano de 1970. Via de regra, a colheita do ano de 1970 teria caído, de qualquer modo, no período baixo de produção, de maneira que a perda de colheita 'real' foi amenizada.

Uma estimativa de colheita da firma Anderson, Clayton \& Co., S.A. indica somente uma produção de 1,16 milhões de sacas, no estado do Paraná, em $1970 .{ }^{281}$ De acordo com observações próprias, o Norte Novo e o Norte Novíssimo foram atingidos em 1970 por uma ausência total de colheita de café, de maneira que o último dado provavelmente corresponde mais à realidade do que a estimativa oficial do IBC de 1,6 milhões de sacas.

A avaliação dos dados sobre colheitas de café de acordo com os anos de geada é especialmente difícil, porque as primeiras estimativas de perda foram determinadas com índices altos por motivos táticos, na esperança de eventualmente receber uma ajuda imediata por parte do governo. Por outro lado, as estatísticas do registro de café282 do IBC incluem igualmente café que, no primeiro momento, se retém dos plantadores após a geada, por especulação de preços e que então, no ano seguinte com a oferta sendo pequena, pode ser posto à venda como nova safra a um preço mais favorável.

\section{CONSEQUÊNCIAS SOCIOGEOGRÁFICAS DIRETAS E INDIRETAS DA GEADA DE 1969}

\section{a) Tendências de desenvolvimento agrário-sociais}

A geada de 10 de julho de 1969 causou um choque nos plantadores de café do Norte do Paraná, especialmente porque, depois de uma primeira avaliação provisória dos danos causados pela geada, já se contava com uma produção nula da colheita em 1970.

Uma grande parte dos plantadores parou todos os investimentos nas plantações de café arruinadas, e a colheita que se acabara de fazer foi retida na esperança de um forte aumento de preços. Muitas vezes, as plantações de café foram abandonadas, sobretudo, nas áreas periféricas meridionais e em áreas localizadas em encostas sul ou bacias (Foto 15).

A imagem da lavoura mostra claramente que os galhos congelados e secos foram retirados somente parcialmente e que árvores completamente mortas não foram erradicadas num primeiro momento. Somente uma parte dos cafeeiros congelados foram cortados a 30-50 $\mathrm{cm}$ acima do solo, para possibilitar que plantas voltassem a brotar e a crescer.

281 "Crop production estimate" de acordo com o Coffee Statistics da firma Anderson, Clayton \& Co, S.A. de 15 de julho de 1970, em Santos, como também informações pessoais do Senhor Fenner, Santos, de 23 de julho de 1970. 1969: 11,14 milhões de sacas; 1970: 1,16 milhões de sacas = perda de produção de $90 \%$.

282 Para 1970: 3,918 milhões de sacas (IBC, Anuário Estatístico do Café, 1972, p. 22). 
O comportamento por parte dos plantadores de café, primeiramente de expectativa, arraigada na esperança por uma ajuda financeira do governo para plantios novos ou para a adaptação a outras culturas, logo se alterou. Um grande número de trabalhadores rurais aos quais se havia cofiado até agora o cuidado dos cafeeiros e que tinham suas residências fixas nas casas de trabalhadores das fazendas e dos sítios foi demitido. Além disso, já era possível antever que as grandes massas de trabalhadores migrantes ficariam desempregadas no ano seguinte, em decorrência da colheita nula.

O número de 10 a 12 mil trabalhadores do Norte Novo e Norte Novíssimo do Paraná que ficou desempregado em decorrência da erradicação de 28 milhões de cafeeiros (GERCA, 1969b, p. 6) após a geada, em 1969, aumentou ainda mais em consequência do abandono de plantações maiores no Noroeste do estado.

O afluxo da população rural, repentinamente desempregada, às cidades de pequeno e médio porte no Norte do Paraná piorou significativamente a situação social que estava tensa naquela região, em decorrência da execução dos programas de erradicação.

Após a recuperação relativamente rápida das plantações de café danificadas pela geada e sobretudo após a florescência intensiva de 1970 - que, depois da colheita quase completamente nula desse ano, foi um indicador de uma boa colheita para $1971^{283}$ — , cada vez mais se fez necessária mão de obra para a limpeza das plantações de café, para o corte dos brotos secos, para capinar etc. As casas desocupadas de trabalhadores das fazendas só paulatinamente foram atribuídas às famílias.

Essa evolução confirma de modo claro, uma tendência que já pôde ser observada a partir da reformulação das leis de direitos sociais rurais: $\mathrm{O}$ abandono de famílias trabalhadoras com base em contratos de trabalhos por tempo indeterminado e assentadas nas terras da fazenda. Danos causados pela geada e o abandono simulado de plantações de café frequentemente serviam apenas de subterfúgio. Para evitar as requisições da legislação agrário-social, muitos trabalhadores rurais foram demitidos de seus contratos fixos nessa ocasião. A readmissão dos trabalhadores rurais demitidos como boias-frias sem contrato estava vinculada a custos baixos e sem qualquer risco para os proprietários de terras. A migração diária das periferias às fazendas da região fez surgir uma relação de emprego totalmente nova e uma situação de ilegalidade trabalhista.

A seguir, analisaremos as bases da legislação social rural e o novo sistema de emprego dos trabalhadores rurais conhecido como 'boias-frias' ${ }^{284}$.

\section{b) Legislação dos trabalhadores rurais e seus efeitos}

Em 1963, durante do governo do presidente Goulart, com o Estatuto do Trabalhador Rural ${ }^{285}$ foi votada uma nova legislação do trabalhador rural que regulava, pela primeira vez de maneira exata, a relação de trabalho e o relacionamento entre empregador e empregado na área rural. Os aspectos mais importantes dessa lei são:

1) Torna-se obrigatória a carteira profissional para todos trabalhadores rurais, que contém, além de dados pessoais, também detalhes sobre o tipo e a duração do contrato de trabalho em cada local de trabalho, e tem a finalidade de ser utilizada em conflitos diante da Justiça do Trabalho e do Seguro Social.

2) Todo empregado na economia rural acima de 16 anos $^{286}$ tem de receber, pelo menos, o salário mínimo previsto pela lei estipulado regionalmente.

Desse salário mínimo, o patrão pode descontar $20 \%$ para o aluguel de uma casa sobre suas terras como também os custos para alimentos postos à disposição. Os preços dos mantimentos, no entanto ao contrário do praticado por muitos proprietários de plantações até agora - não podem estar acima no nível de preço regional comum. Além disso, não se pode descontar mais de $25 \%$ do salário mínimo para mantimentos. As colheitas das plantações intermediárias dos trabalhadores rurais não podem mais ser descontadas do salário por parte do proprietário das terras.

283 De acordo com os mais novos dados do IBC, a colheita de 1971 já voltou a alcançar 12,8 milhões de sacas de café (IBC, Anuário Estatístico do Café, 1972, p. 27-28).

284 Cf. sobre isso a seção (c) adiante.

285 Lei n. 4.214 de 2 de março de 1963; veja também Feteap, 1967: Manual de legislação rural; e Contag: Estatuto do trabalhador rural.

286 Trabalhadores com menos de 16 anos recebem meio salário-mínimo. 
3. A jornada diária é de 8 horas, com uma pausa no meio para alimentação. Horas extras e trabalho noturno são remunerados com um aumento de $25 \%$ sobre salário normal.

4. Além de um dia de repouso remunerado por semana, todo trabalhador tem direito, após 12 meses de trabalho e com não mais que 6 dias de faltas nesse período, a 20 dias de férias remuneradas.

5. No caso de rescisão de um contrato de trabalho assinado com base em prazo indeterminado por parte do empregador, este tem de pagar ao trabalhador rural um salário mensal por cada ano de trabalho - com exceção do período probatório de um ano - como indenização.

6. Depois de 10 anos de serviço, o trabalhador rural alcança a estabilidade e não pode ser demitido, a não ser que tenha cometido erros graves.

7. Para o seguro social ${ }^{287}$ dos trabalhadores rurais e seus familiares dependentes, o empregador tem de pagar o equivalente a $1 \%$ do valor dos produtos agrícolas produzidos por ele. $\mathrm{O}$ assegurado 288 paga uma contribuição anual que corresponde a $8 \%$ do triplo ao quíntuplo do salário mínimo.

Depois da legislação do trabalhador rural ser controlada de maneira extremamente superficial após entrar em vigor, tanto pelo governo esquerdista de Goulart como também, depois do golpe em abril de 1964, pelo governo militar, a situação dos trabalhadores rurais no Brasil quase não mudou até 1967. As determinações legais foram interpretadas de tal maneira que - quando não eludidas - geravam uma desvantagem para o trabalhador rural.

A intensificação dos controles de contratos trabalhistas por meio de órgãos do governo militar desde 1967, o novo texto dos regulamentos legais no contexto do seguro social ${ }^{289}$ como também a organização e o melhoramento da funcionalidade dos sindicatos de trabalhadores rurais ${ }^{290}$ provocaram, como reação por parte dos proprietários de terras, inúmeras demissões de trabalhadores rurais. A geada e as restrições das plantações de café frequentemente proporcionavam somente o motivo aparente para a dissolução aparentemente justificada dos contratos de trabalho. Muitas fazendas de médio e grande porte se esquivaram desse modo da responsabilidade pela segurança social de seus empregados!

Os trabalhadores rurais desempregados e suas famílias se dirigiram aos grandes centros urbanos regionais, diretamente ou após uma procura de trabalho fracassada na zona rural. Logo uma parte desses trabalhadores foi recontratada para o cuidado das plantações de café que estavam se regenerando, para a transição das fazendas para outros produtos de cultivo, ou para a organização de pastagens e a construção de cercas de arame etc.

\section{c) A problemática social do sistema de 'boia-fria' e a mobilidade espacial forçada dos trabalhadores rurais}

Esse novo sistema de contratação baseado no assim chamado sistema de 'boia-fria'291 se diferencia, contudo, de maneira fundamental da antiga situação de emprego dos trabalhadores rurais assegurada, ao menos temporariamente, por um contrato de trabalho. Esses trabalhadores agora vivem nas favelas, que crescem rapidamente e medram nas periferias (Foto 12), e não mais nas casas de trabalhadores dos sítios e fazendas. Eles se transformaram, em grande parte contra sua vontade, em 'jornaleiros' que vão e voltam diariamente; eles não são mais dependentes do proprietário de terra, mas sim do assim chamado 'gato', geralmente o proprietário de um ou mais caminhões.

Esse 'gato' intervém como mediador de trabalho e age como 'corretor de mão de obra'. Ele não dá qualquer tipo de seguro social.

O recrutamento da mão de obra de boias-frias acontece diariamente, de madrugada, entre 4 h30 e 6h, em locais de encontro na periferia (em Londrina, por exemplo, na favela de Shangri-lá), nos quais

287 Funrural: Fundo de Assistência e Previdência do Trabalhador Rural. O seguro abarca vantagens como assistência médica, apoio quando de nascimentos e mortes, como também pensão por invalidez e para família do falecido.

288 Obrigatoriamente assegurados são trabalhadores rurais, arrendatários, empreiteiros e proprietários de pequenas propriedades. Desde o começo de 1970, existe um seguro público de acidentes para trabalhadores rurais registrados.

289 Cf. sobre isso Contag: Fundo Rural (de acordo com o Decreto Lei n. 276, 28.2.1967).

290 Sobre as tarefas dos 110 sindicatos rurais no Paraná, veja Fetaep (1967, p. 3ss.), bem como também informações orais fornecidas pelo Senhor J. Lazaro Dumont, presidente da Federação dos Trabalhadores na Agricultura do Estado do Paraná, no dia 11 de agosto de 1970, em Londrina.

291 O termo coloquial 'boia-fria' é derivado da comida levada numa panela (arroz, feijão, farinha de mandioca) e esquentada na hora do almoço pelos trabalhadores rurais. 
os caminhões levam respectivamente 50-70 trabalhadores, conduzindo-os a uma determinada fazenda (Foto 11), frequentemente a uma distância de $30 \mathrm{~km}$ ou mais. Em certos dias, aparecem mais de 50 caminhões $^{292}$. O número de pessoas que procura emprego nesse sistema de bóia-fria alcançou em 1970 picos diários de até 3000 pessoas na cidade de Londrina, cuja idade oscilava entre 13 e 55 anos.

Como o 'gato' frequentemente é contratado na função de empreiteiro para trabalhos de empreitada em propriedades maiores, ele está interessado em homens jovens e fortes sob seu comando para realizar esse trabalho, escolhidos por ele nos pontos de encontros entre aqueles que estão esperando. O proprietário de terra somente negocia com o 'gato' e paga a este, em geral, diariamente a quantia estipulada. O gato desconta do ganho diário dos trabalhadores rurais - que recebem cerca de NCr\$ 4,50 a 5,50 (junho de 1970: 1 NCr\$= 0,85 DM) - de NCr\$ 1,00 a NCr\$2,50 pelos custos de transporte de e para o local de trabalho! O valor dos custos de transporte é determinado ${ }^{293}$ pelo 'gato', frequentemente de acordo com a idade ou a capacidade de trabalho, significando, além disso, um ganho considerável.

O salário de empreitada para os diferentes trabalhos foi pago, em junho de 1970, em média com as seguintes quantias por pessoa:

Colheita de milho
Colheita de café (Norte Velho)
Colheita de cana-de-açúcar
Colheita de algodão
Colheita de feijão

Os salários de empreitada são escalonados de maneira que o trabalhador poderia alcançar o salário mínimo com 30 dias de trabalho, porém nos finais de semana não há trabalho, e os altos custos de transporte reduzem o ganho do trabalhador em 20 a 40\%. Além disso, os trabalhos tomados por base a serem realizados geralmente são bastante pesados e só podem ser feitos por trabalhadores jovens.

A migração diária de ida e volta dos boias-frias - das áreas residenciais, na periferia urbana, às fazendas rurais de médio e grande porte na região - foi analisada mais detalhadamente pelo exemplo de Londrina ${ }^{294}$. No Norte Novo do Paraná, sobretudo na área de colonização da Cia. Terras Norte do Paraná (já denominada Cia. Melhoramentos Norte do Paraná/CMNP, à época da pesquisa), a alta porcentagem de propriedades de pequeno e médio porte atenuou a problemática e as consequências do sistema de 'boia-fria'.

Como a antiga área da CMNP tem seu extremo sudeste perto de Londrina; o limite com as grandes fazendas mais afastadas transcorre no norte a somente cerca de $18 \mathrm{~km}$, e no sul a $15 \mathrm{~km}$ de Londrina; e como muitos trabalhadores rurais que anteriormente tinham um contrato fixo se assentaram na periferia da cidade grande após serem demitidos, pode-se observar especialmente bem nessa área o fenômeno de mobilidade de boias-frias.

A Figura 8 mostra a distribuição percentual dos lugares de trabalho de boias-frias, a partir da respectiva distância das fazendas da cidade de Londrina e sua localização.

292 Em primeiro de junho de 1970, o primeiro dia da entrevista realizada pelo autor em Londrina, somente 5\% dos caminhões para o transporte dos boias-frias foram providenciados pelos proprietários de terra.

293 Esses dados e as exposições seguintes são o resultado de entrevistas realizadas pelo Autor com boias-frias, num local de encontro em Londrina e em fazendas nos municípios de Rolândia e Londrina. Para a avaliação da situação geral, recorreu-se também a relatórios de filiais dos Sindicatos dos Trabalhadores Rurais, às quais foi possível ter acesso na Fetaep, em Londrina. O Autor agradece aqui também ao Senhor J. L. Dumont pelas inúmeras informações e pelo apoio na aquisição de documentos.

294 Entrevistas realizadas pelo Autor com 237 pessoas em diferentes lugares de encontro de boias-frias, em $1^{\circ}$ de junho e 2 de junho de 1970, como também no Sindicato dos Trabalhadores Rurais em Londrina em 11 de agosto de 1970. 
Figura 8: Regiões alvo dos trabalhadores pendulantes boias-frias vindos de Londrina, segundo a distância e a distribuição quantitativa

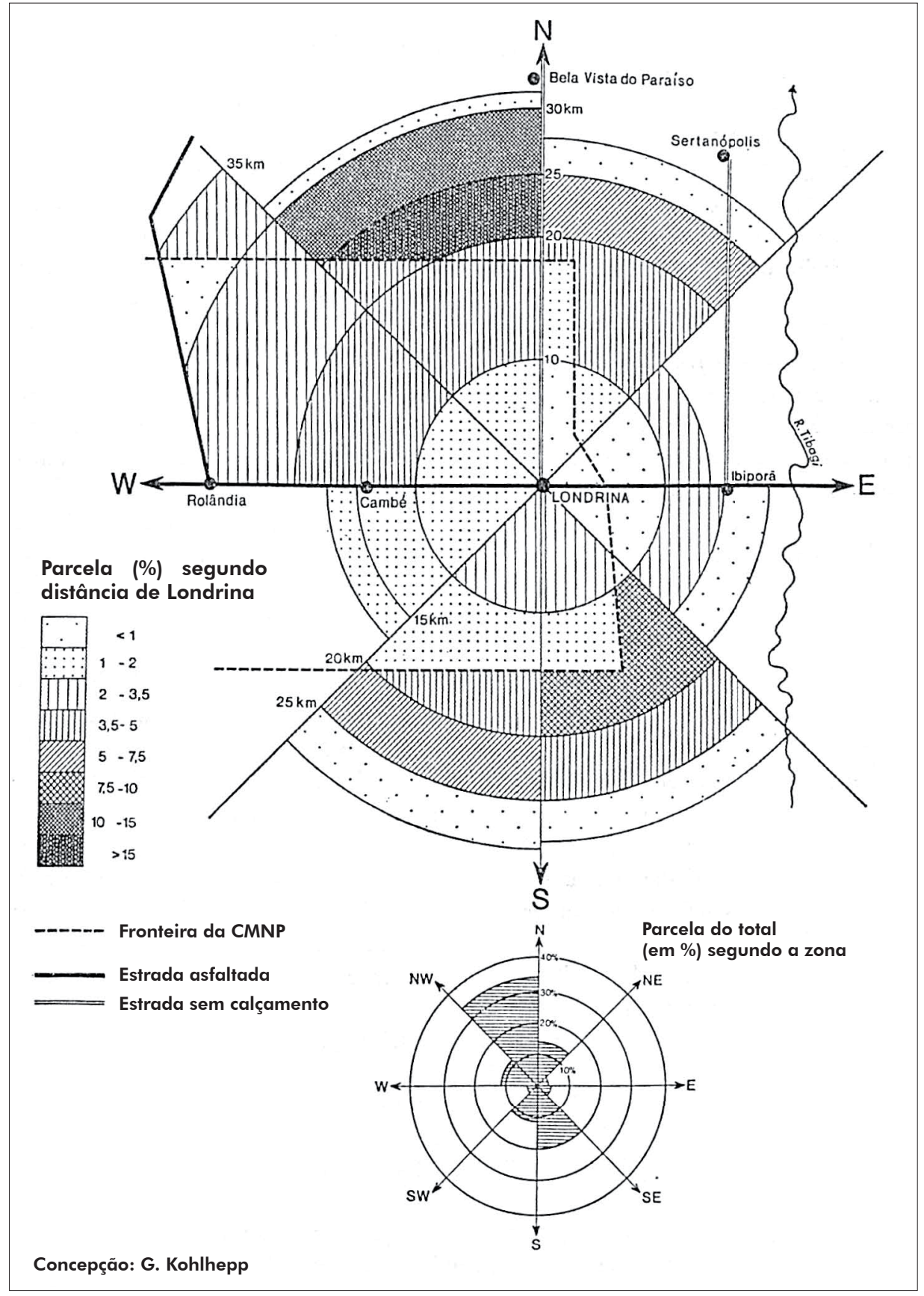

Fonte: Entrevistas do Autor em $1^{\circ}$ e 2 de junho de 1970.

O ponto de concentração de emprego claramente fica fora dos limites da CMNP, sobretudo no Noroeste, onde um número de grandes fazendas faz limite diretamente com as terras da antiga companhia de colonização. $16 \%$ dos boias-frias que fazem viagens de ida e volta ao trabalho a partir de Londrina estão empregados nessa região entre $20-25 \mathrm{~km}$, e $12 \%$ entre 25 e $30 \mathrm{~km}$ de distância da cidade. No total, $33 \%$ do total de trabalhadores pendulares de Londrina estava empregada na região entre o noroeste e o norte, e a maior distância entre a moradia e o local de trabalho dos entrevistados chegava aqui a $32 \mathrm{~km}$ em linha reta (cerca de $46 \mathrm{~km}$ de viagem). 
No oeste e especialmente no sudoeste, somente uma pequena quantidade de trabalhadores boiasfrias estão empregados, pois nessa região predominam as pequenas propriedades. A quantidade de trabalhadores boias-frias ocupados é, na região imediatamente ao sul de Londrina, um pouco maior do que nas regiões próximas equidistantes da cidade, devido às muitas propriedades adjacentes. Seguese uma zona intermediária relativamente estreita com pequenas propriedades e pouca demanda por trabalhadores, próximo da fronteira sul da CMNP. A isso segue-se, sobretudo no sudeste, uma região com grande quantidade de jornaleiros pendulares a uma distância entre 10 e 15-20 km da cidade (cerca de $9 \%$ da quantidade total dos trabalhadores boias-frias entrevistados e que moravam em Londrina).

Mais para o sul, a influência da migração pendular de Londrina diminui muito rapidamente, uma vez que a quantidade de propriedades agrícolas dependentes de trabalhadores boias-frias é muito menor, devido à fronteira climática para o cultivo do café, que passa a cerca de 40-50 km ao sul de Londrina.

A região a leste de Londrina, de Ibiporã a Sertanópolis, foi agrimensada em pequenas propriedades no início da colonização a oeste do rio Tibagi por companhias privadas - da mesma forma que a região da CMNP - , necessitando portanto de pouca mão de obra adicional e tendo um papel relativamente reduzido para os trabalhadores pendulares (Figura 8).

Ao se analisar a expansão e a amplitude espacial do movimento pendular cidade-campo com ponto de partida em Londrina, deve-se levar em conta que, ao longo dos eixos rodoviário e ferroviário para o leste e sobretudo para o oeste, os movimentos pendulares próprios de Ibiporã, Cambé, Rolândia etc. se sobrepõem aos movimentos pendulares de Londrina, e colocam limites à influência de longa distância deles.

O problema dos boias-frias no Norte do Paraná levou a grande agitação, instatisfação geral e a confrontos públicos ${ }^{295}$. Muitos fazendeiros afirmam não estar mais em condições de empregar uma grande quantidade de trabalhadores fixos com famílias numerosas, devido às obrigações determinadas pela legislação dos trabalhadores agrícolas e, além disso, devido aos danos causados pela geada ${ }^{296}$.

Por outro lado, inúmeros trabalhadores rurais pensam haver sido demitidos injustamente às custas da sua seguridade social e sem acerto de contas. As queixas dos trabalhadores sobre o não cumprimento das obrigações legais por parte dos proprietários de terras se empilham nos escritórios dos sindicatos locais. Só em Londrina, no primeiro semestre de 1970 entravam diariamente de 30 a 40 trabalhadores rurais com queixas contra seus antigos empregadores. Nas disputas trabalhistas até o momento da pesquisa haviam se decidido vários casos litigiosos em favor dos reclamantes, e paralelamente houve também uma grande quantidade de acordos. Em junho de 1970, a quantidade de trabalhadores rurais que recebiam o salário mínimo determinado por lei $^{297}$ no Norte do Paraná era estimada em pouco mais de $5 \%{ }^{298}$.

Em proveito dessa situação, surgiu um tipo de assistência jurídica ambulante, conduzida por advogados experientes na área agrícola e que não raro convenciam os trabalhadores a entrar com processos, nos quais, em caso de decisão favorável ao colono, frequentemente uma grande parte da indenização acabava ficando em mãos do advogado. Por outro lado, comprovaram casos - a quantidade de números não oficiais é, contudo, extraordinariamente alta - nos quais os advogados se uniam com os proprietários de terras, de modo que cada ganho de causa implicasse o pagamento ou de um honorário mais elevado ou de uma indenização menor, em desvantagem para o trabalhador dentro da lei. Essa forma de ajuda jurídica foi recusada também pelos sindicatos de trabalhadores rurais, que preferiam centralizar o cuidado dos casos.

No total, deve-se contar com uma grande quantidade de casos nos quais os colonos aceitam condições extremamente ruins por medo de serem demitidos, de modo a garantir um mínimo de subsistência para suas famílias.

Os proprietários das terras não colocam a culpa por todo o problema somente nos danos da geada de 1969, mas também no governo, já que a alta taxação pelo 'confisco cambial' na exportação reduziu a receita das colheitas de café em cerca de $50 \%$. De fato, o governo brasileiro falhou ao não criar novas

295 Em maio e junho de 1970, foi publicada no jornal londrinense Folha de Londrina uma grande quantidade de reportagens, denúncias e defesas, bem como inúmeras cartas e opiniões sobre o problema dos trabalhadores boias-frias.

296 Na discussão pública, os familiares menores de idade dos 'colonos' eram chamados da parte de alguns fazendeiros de 'almas mortas' ou 'boca fria', descrevendo a pouca 'utilidade' deles como mão de obra!

297 Cr\$170,00/mês = 140 DM segundo a cotação de junho de 1970.

298 Informações cedidas pelo Sr. J. L. Dumont, Londrina, presidente da Fetaep. 
iniciativas, elevando o preço ao produtor após os péssimos resultados das colheitas de café daqueles últimos anos. A lavoura de café, que oferece como único cultivo a possibilidade de trabalho permanente a uma parcela relativamente grande da mão de obra, sofria naquele momento, pela maior necessidade de adubação, com os altos preços dos adubos, pesticidas etc. produzidos no Brasil, os quais, devido à taxação adicional, em parte tinham preço mais alto do que o de produtos estrangeiros. Esse é o caso, por exemplo, de fertilizantes nitrogenados, extremamente necessários para a agricultura.

Por outro lado, a política de diminuição dos preços ao produtor está direcionada a produtos agrícolas - exceto o cafée 299 - e à fixação dos preços mínimos segundo padrões internacionais que, contudo, conhecem um alto grau de todo tipo de mecanização, adubação, subvenções e consultoria.

Até agora não se conseguiu quebrar o círculo vicioso. Os baixos preços ao produtor trazem pouca ou nenhuma vantagem ao consumidor, devido à disseminação e diversificação dos atravessadores. A tentativa dos produtores de aumentar as receitas sobretudo com as lavouras de milho, arroz, feijão, soja e trigo com a melhoria dos métodos agrícolas - como medidas antierosão, mecanização, adubação e medidas fitossanitárias - e, com isso, de equiparar os baixos preços ao produtor, frequentemente falha devido aos custos elevados. $\mathrm{O}$ apoio garantido pelo governo para a indústria brasileira em rápido desenvolvimento - frequentemente subsidiárias de grandes conglomerados estrangeiros - se dá portanto largamente às custas das camadas mais pobres da população.

Uma vez que a agricultura demanda muita mão de obra devido à baixa mecanização, a reorganização da legislação trabalhista agrícola e as obrigações sociais correspondentes levaram, nas propriedades maiores, a uma forte tendência da pecuária extensiva, que consegue se manter a longo prazo com pouco investimentos e com uma quantidade de trabalhadores muito menor. A proporção de reserva de mão de obra entre uma propriedade dedicada à pecuária extensiva e uma fazenda de café do mesmo tamanho é de cerca de 1:30.

A determinação de se proibir a dedução das receitas de entressafra do salário dos trabalhadores rurais, ancorada na legislação social agrária, foi preparada pelos legisladores certamente com as melhores intenções de evitar uma discriminação dos colonos. Contudo, é justamente na lavoura de café do Paraná que essa passagem do texto não se mostra necessariamente favorável aos colonos. No antigo sistema de colonato, além de um valor fixo por quantidade de cafeeiros trabalhados, havia também uma grande parte dos lucros das plantações intermediárias, que eram feitas em acordo com o patrão quanto à época do plantio, ao tipo da cultura e também à quantidade de fileiras intermediárias de milho, arroz e feijão.

Para muitos colonos, a venda dos produtos de cultivo intermediário com frequência era uma preparação para atingir a independência econômica. Os férteis solos de terra roxa davam grandes colheitas, com cujos lucros se adquiria terra barata na frente pioneira e com isso se lançava a pedra fundamental de uma economia independente.

Atualmente o proprietário de terras deve pagar aos trabalhadores rurais o salário mínimo estabelecido por lei. Ao lado disso, ele não tem em geral mais nenhum interesse em repassar as lavouras intermediárias para os colonos, comercializando-as ele mesmo. No interesse de um cuidado diligente das plantações de café, alguns proprietários de terra ainda dão mesmo hoje em dia uma pequena parte dos lucros das colheitas intermediárias.

De maneira geral, contudo, a regulamentação legal organizada das relações de trabalho e a fixação de salários mínimos baixos demais dificultaram a iniciativa própria e a mobilidade social dos colonos, já reduzidas nas zonas pioneiras. De fato, o salário mínimo garante em geral a subsistência, contudo a eliminação dos cultivos intermediários da área de influência econômica dos colonos tornou impossíveis, naquele momento, as chances de ascensão deles por meio do próprio trabalho.

Em face disso deve-se levar em conta, contudo, que com o assentamento de populações do Norte do Paraná no contexto da expansão cafeeira as novas áreas de terra nas regiões Sul e Sudeste brasileiras estão esgotadas. Atualmente, a compra de terras no Norte Novo e no Norte Novíssimo são praticamente impraticáveis para os colonos, devido aos altos preços das terras.

Levantamentos estatísticos realizados no Norte do Paraná entre maio e outubro de 1970 mostram que, em média, somente de 15 a 30\% dos colonos necessários nas plantações de café e antigamente com

299 Segundo dados de plantadores de algodão, em 1970 o preço da arroba do algodão de NCr\$ 8,70 não chegava para cobrir os custos. O mercado brasileiro do algodão é fortemente influenciado - e, em parte, manipulado - por grandes grupos estrangeiros. De 1968 a 1969, a área de cultivo do algodão no Paraná foi ampliada em 75\%; a colheita, contudo, foi a pior dos últimos 30 anos, em parte devido à falha de orientações e consultoria técnicas para os plantadores, inexperientes com o cultivo do algodão. 
emprego fixo ainda têm suas residências nas plantações e fazendas. Os restantes foram dispensados ou migraram - em quantidade muito menor - em pequenos grupos para as cidades médias e pequenas, e foram substituídos por jornaleiros. Assim, muitas casas de trabalhadores das plantações de café estão vazias.

Da mesma maneira que essas moradias são casas de madeira muito simples e pequenas demais para as grandes famílias, cobertas de telhas e sem qualquer conforto, encontram-se nas proximidades das casas instalações sanitárias em geral muito primitivas. Poços localizados a uma distância segura das fossas garantem um fornecimento de água perfeito. O controle do serviço de proteção contra a malária e as inspeções para prevenção de outras doenças infecciosas são realizadas frequentemente nas casas dos trabalhadores.

Os trabalhadores empregados no sistema de boias-frias informaram que o motivo para uma emigração espontânea ${ }^{300}$ para as periferias das cidades foi a possibilidade adicional de uma ocupação assalariada das esposas e das filhas mais velhas em casas na cidade ou prestando outros serviços simples. Ao lado disso, foram mencionados também o alugel alto demais das casas de trabalhadores na fazenda, péssimo tratamento e insatisfação com o trabalho e com a vida no campo, melhores condições de educação na cidade para as crianças, possibilidades de ganho adicional como lavador de carros, ajudante, mensageiro, engraxate etc., bem como o atrativo de passatempos 'urbanos' como cinema, futebol ou de maneira geral o 'ambiente'.

Nessa situação faltam às famílias, alojadas nos bairros rapidamente crescentes das favelas, tanto alimentos básicos quanto as instalações higiênicas mais básicas. Frequentemente também não há fornecimento limpo de água potável. Os barracos feitos de restos de madeira, papelão, chapas de metal e galões de plástico (Foto 12) oferecem condições sanitárias piores dos que as oferecidas nas casas de trabalhadores no campo; por outro lado, aqui pelo menos não há custos com aluguel. Por outro lado, crescem muito a delinquência e a prostituição, especialmente porque as favelas das cidades do Norte do Paraná já estão superlotadas devido à migração interna para o estado e por ser difícil para os agricultores não escolarizados arranjar oportunidades de emprego fixo nas cidades. $\mathrm{O}$ desenvolvimento industrial do Norte do Paraná avançou, até o momento, com relativa lentidão e oferece poucos postos de trabalho.

A migração pendular para as propriedades agrícolas maiores no contexto do recrutamento de boiasfrias (Foto 11) é vital para a maior parte dos migrantes, mesmo com a pior exploração por parte do 'gato'.

As condições de moradia e de salário dos moradores das favelas ficam evidentes com base em uma pequisa feita em Londrina ${ }^{301}$ : em 1970 viviam 981 pessoas nas 181 moradias da Favela da Caixa Econômica, das quais 50,2\% tinham menos de 14 anos de idade. $38 \%$ dos barracos possuíam somente um cômodo, 71 \% com chão de terra batida. As condições sanitárias e higiênicas são extremamente precárias.

De 470 pessoas em idade ativa entre 14 e 60 anos de idade $(=47,9 \%), 271$ informaram ter uma ocupação ou emprego (57,7\%), e cerca de $30 \%$ já tinham se sujeitado a trabalhar como jornaleiros boiasfrias. $41 \%$ das pessoas acima dos 7 anos de idade são analfabetas, $59 \%$ são supostamente alfabetizados, isto é, uma grande parte sabe somente escrever o próprio nome (condição básica para o direito ao voto) e ler com dificuldades. Somente $6 \%$ tinham terminado o ensino primário.

Das 271 pessoas com alguma ocupação:

65\% recebiam menos que o salário mínimo legal por mês ${ }^{302}$

16\% recebiam aproximadamente o salário mínimo

10\% recebiam mais do que o salário mínimo (em parte devido a mais de um trabalho)

9\% $\quad$ sem dados

300 9\% dos entrevistados informaram ter abandonado espontaneamente as plantações de café. Uma parte desses migrantes certamente só estava se antecipando à demissão vindoura.

301 Resultados de uma entrevista realizada em junho de 1970 na Favela da Caixa Econômica em Londrina, ao norte da BR 369 sentido Cambé, km 01, com complementações de investigações do Ministério da Saúde, Departamento Nacional de Endemias Rurais, Posto de Esquistossomose de Londrina.

302 O salário mínimo mensal para um adulto por 30 dias de trabalho ou 240 horas de trabalho mensais correspondia, em $1^{\circ}$ de maio de 1970, na $1^{\circ}$ microrregião do Paraná - isto é, nos municípios economicamente significativos - a NCr\$170,40 (para se ter um valor de comparação, um almoço muito simples na região agrícola do Norte do Paraná custava, à mesma época, de $\mathrm{NCr} \$ 5,00$ a NCr\$ 6,00, isto é, o ganho de um dia de trabalho). 
Para o morador da favela, o trabalho como jornaleiro nas fazendas da região não era de maneira nenhuma uma ocupação adicional, mas sim a fonte principal de renda.

O problema dos boias-frias não surgiu somente nas cidades maiores do Norte do Paraná Londrina e Maringá -, mas também apareceu em Cambé, Bela Vista do Paraíso, Ibiporã, Nova Esperança, Paranavaí, Marialva e Itambé, e também no Norte Velho (sobretudo Jacarezinho e Cornélio Procópio).

O afastamento do sistema de colonato das tradicionais lavouras de café paulistanas já tinha começado anteriormente nas lavouras de algodão e de cana-de-açúcar do estado de São Paulo e no Norte Velho do Paraná.

A questão sobre o sistema de boias-frias, marcado por uma alta mobilidade espacial, ser uma ocorrência passageira na lavoura de café como consequência de grandes perdas na colheita causadas pela geada, ou uma ocorrência duradoura, tendo-se em vista as disposições de legislação social para os trabalhadores rurais, não é passível de ser respondida definitivamente no momento em que se escreve este livro.

Ao governo restam certas medidas para controlar as relações trabalhistas agrárias por meio da elevação dos preços do café para o produtor. Mesmo várias grandes propriedades preferem ter força de trabalho confiável e fixa à flutuação diária dos inexperientes trabalhadores boias-frias.

Depois de terminada a fase pioneira, a agricultura do Norte do Paraná apresenta, por um lado, diversos problemas naturais: erosão do solo, grande diminuição da fertilidade do solo, instabilidade das condições de precipitação, danos causados por geadas e ataques de pestes.

Por outro lado, essa crítica situação de transição é reforçada por absentismo, relações de arrendamento de curto prazo, pouca experiência agrícola para além da lavoura de café, problemas da segunda cultura depois do café, mobilidade espacial dos trabalhadores rurais, venda de terras e especulação.

A geada de 1969 produziu tanto consequências 'diretas' (queda na colheita, abandono de plantações de café, mudanças na estrutura de uso da terra) dos quais decorreu a perda do emprego para inúmeros trabalhadores rurais, quanto também consequências negativas 'indiretas', em especial a tentativa motivada pelos danos das geadas de se contornar as leis sociais na região agrária, pela rescisão de contratos de trabalho.

O maior perigo para as relações sociais agrárias advém, contudo, da tendência de muitos proprietários de terra de procurarem uma "solução" dos problemas pendentes e uma maneira de evitar maiores contribuições previdenciárias pela transferência para a pecuária extensiva com muito pouca demanda de mão de obra.

Em regiões com condições ecológicas desfavoráveis e perigo permanente de geadas devido à localização, essa transferência é necessária; em todas as outras áreas ela é principalmente um desenvolvimento da especulação condicionada pela conjuntura, com sérias consequências sociais. 